\title{
High YKL-40 serum levels and its expression in the muscle tissues of patients with antisynthetase syndrome
}

\author{
Renata Casseb de Souza Carboni, Gustavo Luiz Behrens Pinto and Samuel Katsuyuki Shinjo *D
}

\begin{abstract}
Background: The protein chitinase-3-like-1 (YKL-40) is rarely analyzed in patients with myositis. Therefore, we aimed to evaluate YKL-40 serum levels; correlate them with laboratory and clinical parameters, disease status, and treatment schemes; and analyze the YKL-40 expression in the muscle tissues of patients with antisynthetase syndrome (ASSD).

Methods: This cross-sectional single-center study included 64 adult patients with ASSD who were age-, gender-, and ethnicity-matched to 64 healthy control individuals. Their YKL-40 serum levels were analyzed using the Enzyme-Linked Immunosorbent Assay (ELISA) kit method, while YKL-40 expression in muscle tissues was analyzed using an immunohistochemical technique. Disease status was assessed using the International Myositis Assessment and Clinical Studies Group (IMACS) set scores.

Results: The patients' mean age was $44.8 \pm 11.8$ years, and median disease duration was $1.5(0.0-4.0)$ years. These patients were predominantly female (82.8\%) and Caucasian (73.4\%). Most patients had stable disease. The median YKL-40 serum level was significantly higher in patients with ASSD when compared to the healthy individuals: 538.4 (363.4-853.1) pg/mL versus 270.0 (201.8-451.9) pg/mL, respectively; $P<0.001$. However, YKL-40 serum levels did not correlate with any clinical, laboratory, disease status, or therapeutic parameters $(P>0.050)$, except tumor necrosis factor alpha (TNF-a) serum levels (Spearman's correlation, $r h o=0.382 ; P=0.007$ ). YKL-40 was highly expressed by inflammatory cells found in muscle biopsy specimens.

Conclusions: High YKL-40 serum levels were observed in patients with ASSD and correlated positively with TNF- $a$ serum levels. Moreover, YKL-40 was expressed by the inflammatory cells of the muscle tissue.
\end{abstract}

Keywords: Antisynthetase syndrome, Chitinase, Inflammatory myopathy, Muscle biopsy, Myositis

\section{Introduction}

Antisynthetase syndrome (ASSD) is a rare systemic autoimmune myopathy characterized by muscle, joint, and pulmonary involvement, as well as by the presence of fever, "mechanic's hands," and Raynaud's phenomenon [1-4]. In the laboratory, the ASSD is characterized by the presence of anti-aminoacyl-tRNA synthetase autoantibodies, such as anti-Jo-1 $[1,2]$.

\footnotetext{
* Correspondence: samuel.shinjo@usp.br

Division of Rheumatology, Faculdade de Medicina FMUSP, Universidade de Sao Paulo, Av. Dr. Arnaldo, 455, $3^{\circ}$ andar, sala 3184 - Cerqueira César. CEP:
} 01246-903, Sao Paulo, Brazil

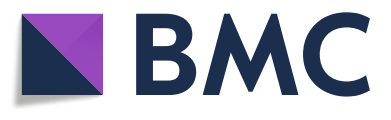

The protein chitinase-3-like-1 (YKL-40) is a glycoprotein secreted by inflammatory cells, including macrophages and neutrophils $[5,6]$. YKL-40 is associated with several physiological processes, such as inflammation, cell proliferation, angiogenesis, tissue fibrosis, and tissue remodeling [7]. YKL-40 also participates in a wide range of inflammatory responses, also stimulating the production of pro-inflammatory cytokines (e.g., IL-6, IL-18, and tumor necrosis factor alpha $[\mathrm{TNF}-\alpha])$, which are capable of increasing YKL-40 serum levels as a feedback mechanism $[8,9]$.

(c) The Author(s). 2021 Open Access This article is licensed under a Creative Commons Attribution 4.0 International License, which permits use, sharing, adaptation, distribution and reproduction in any medium or format, as long as you give appropriate credit to the original author(s) and the source, provide a link to the Creative Commons licence, and indicate if changes were made. The images or other third party material in this article are included in the article's Creative Commons licence, unless indicated otherwise in a credit line to the material. If material is not included in the article's Creative Commons licence and your intended use is not permitted by statutory regulation or exceeds the permitted use, you will need to obtain permission directly from the copyright holder. To view a copy of this licence, visit http://creativecommons.org/licenses/by/4.0/. 
High YKL-40 serum levels have been described in osteoarthritis [10] and in several systemic autoimmune diseases, such as rheumatoid arthritis [11-14], giant cell arteritis [15], systemic sclerosis [16, 17], Takayasu's arteritis [18], and systemic autoimmune myopathies [19-21].

In rheumatoid arthritis, YKL-40 serum levels are not only increased but also correlate positively with the disease activity [11-13]. However, YKL-40 is not associated with radiographic progression or predictive values for disease remission [14]. In patients with systemic sclerosis, YKL-40 serum levels correlate mainly with joint involvement [16], lung involvement (fibrosis or reduction in the diffusing capacity for carbon monoxide [DLCO]), digital articular deformities through cutaneous retraction, and reduced patient survival [17]. High YKL-40 serum levels are also described in patients with dermatomyositis and polymyositis, correlating with the disease activity and severity and with pulmonary involvement [19-21].

However, no studies have assessed YKL-40 serum levels exclusively in patients with ASSD, which was the primary motivation for this study. We aimed to correlate YKL-40 serum levels with clinical and laboratory parameters, disease status, and therapeutic schemes, as well as to analyze the YKL-40 expression in muscle tissue specimens from patients with ASSD.

\section{Patients and methods}

This cross-sectional single-center study took place from 2017 to 2019 and included 66 adult patients with ASSD followed up at the outgoing clinic of our service. All patients fulfilled the modified ASSD criteria classification proposed by Connors et al. [1], but with modifications to increase its specificity, including the presence of at least two of the following three manifestations: muscle, joint, and lung involvement; and in addition to persistent fever; Raynaud's phenomenon; "mechanic's hands;" and the presence of serum anti-aminoacyl-tRNA synthetase autoantibody.

Muscle involvement was defined as the presence of progressive and proximal limb muscle weakness, increased serum levels of muscle enzymes, such as creatine phosphokinase (CPK), myopathic pattern on electroneuromyography, and muscle biopsy compatible with inflammatory myopathy. Joint involvement was defined as non-deforming and non-erosive arthritis or arthralgia. Additionally, as part of the internal protocol of our service, patients underwent computed tomography (CT) chest scans at disease onset and during follow-up. In this study, lung involvement was defined as the presence of incipient pneumopathy, pulmonary nodules, ground-glass opacities with or without bronchiectasis, and pulmonary fibrosis (e.g., honeycombing areas).
A commercially available line blot test kit (Myositis Profile Euroline Blot test kit, Euroimmun, Lübeck, Germany) was used to identify anti-aminoacyl-tRNA synthetase autoantibodies (anti-Jo-1, anti-EJ, anti-OJ, anti-PL-7, anti-PL-12, and anti-Ro-52). The assessment was performed according to previously established methods [22]. The immunological patterns evaluated were antinuclear antibodies (ANA) detected by an indirect immunofluorescence technique on HEp-2 cells.

We excluded pregnant patients and those with other systemic autoimmune diseases (overlap syndrome), chronic or acute infection, neoplasia-associated myositis, and uncontrolled and serious comorbidities (e.g., liver disease, nephropathy, and heart disease). Observing the internal protocol of our service, a screening for neoplasms and other lung diseases was performed in all cases of myopathies.

The following pre-standard and pre-parameterized data were collected from the patients' interviews: demographic information (current age, gender, ethnicity), clinical information (disease duration; muscle, pulmonary, and joint involvement; Raynaud's phenomenon; presence of fever; and "mechanic's hands"), laboratory findings (serum levels of CPK, lactate dehydrogenase, aspartate aminotransferase, alanine aminotransferase), disease status, treatment (immunosuppressive, immunomodulatory, and glucocorticoid therapies), and comorbidities. Moreover, on the interview day, blood samples $(20 \mathrm{~mL})$ were taken for laboratory analysis after an eight-hour fasting.

Current clinical and laboratory disease status was assessed by applying the following questionnaires and International Myositis Assessment \& Clinical Studies Group (IMACS) scores: Myositis Disease Activity Assessment Visual Analogue Scales (MYOACT) [23, 24], Manual Muscle Testing (MMT-8) [25], overall disease assessment by a physician and by the patient using a visual analogue scale (VAS) [26], and the Health Assessment Quality (HAQ) [27].

Pulmonary assessment was performed using chest CT images. The following parameters were investigated: incipient pneumopathy, ground-glass opacities with or without bronchiectasis, pulmonary nodules, and pulmonary fibrosis (honeycombing areas) [1, 28, 29]. All chest CT images were analyzed independently by the two authors of the present study, who are experienced in connective tissue diseases (RCSC and GLBP). In case of disagreement between them, the images were discussed with radiology groups from our institute.

Chest CT images obtained during a period ranging from six months before to six months after the patients' participation were included in this study. When possible, the pulmonary assessment was supplemented by a pulmonary function test that considered the forced expiratory volume in one second (FEV1), forced vital capacity (FVC), FEV1/ FVC ratio, and DLCO. 
The patients with ASSD were gender-, age-, and ethnicity-matched to healthy control individuals (patients' relatives or employees of our service) selected for convenience. All laboratory tests were performed on the control group, and they were asked to answer all interview questions, except those related to the disease data.

For the cytokine assessment, the material was centrifuged at $3000 \mathrm{rpm}$ for $10 \mathrm{~min}$ immediately after blood collection $(<30 \mathrm{~min})$, and the sera were aliquoted and stored at $-80^{\circ} \mathrm{C}$ for further cytokine analysis. The YKL-40 quantification was performed using a specific kit (Human CHI3L1 ELISA kit, RayBiotech, USA) and processed following the manufacturer's protocol. The interferon gamma (IFN- $\gamma$ ) and TNF- $\alpha$ tests were performed using the LUMINEX 100/200x xMAP technology (Millipore, USA), as described elsewhere [30].

Additionally, the YKL-40 expression and location were assessed in muscle tissues of three patients with ASSD, whose biopsies were taken from the vastus lateralis muscle upon diagnosis. Sequential $5-\mu \mathrm{m}$ thick frozen sections were first stained by hematoxylin-eosin and, then, immunohistochemistry was performed. For immunohistochemical analysis, monoclonal antibodies (CD4, CD8, CD68, and YKL-40: Abcam, USA) were used. Frozen specimens were fixed for $10 \mathrm{~min}$ in acetone at $4{ }^{\circ} \mathrm{C}$. Endogenous peroxidase was blocked using $1 \%$ $\mathrm{H}_{2} \mathrm{O}_{2}$ in absolute methanol three times for $10 \mathrm{~min}$. After rinsing the specimens in phosphate buffered saline (PBS) $(0.01 \mathrm{M}, \mathrm{pH} 7.4)$ for five minutes, these were incubated in fetal serum in a wet chamber for one hour at $37^{\circ} \mathrm{C}$. Primary antibodies were diluted in PBS and albumin from $1 \%$ bovine serum was applied in wet chamber at $37^{\circ} \mathrm{C}$ overnight. Next, slides were washed in PBS and a secondary mouse biotinylated solution (StreptABComplex/HRP) was applied for $30 \mathrm{~min}$ at $37^{\circ} \mathrm{C}$ and rinsed in PBS. Then, the prepared StreptABComplex/HRP complex was applied and incubated for $30 \mathrm{~min}$ at $37^{\circ} \mathrm{C}$. After rinsing in PBS and incubation, the reactions were visualized using a solution of chromogenic substrate (3,3'-diaminobenzidine tetrahydrochloride) for peroxidase. After a final rinse, hematoxylin counterstaining was performed. The slides were then mounted and covered with an aqueous-based mounting medium. All muscle specimens were prepared at the same time as a batch. Human amygdala was used as a positive control, while a muscle specimen from a patient with ASSD, but whose biopsy results were normal (without infiltrate inflammation), was used as a negative control. Inflammatory cell phenotyping (CD4, CD8, CD68, and YKL-40) was analyzed in the endomysium, perimysium, and pericapillary (endomysium and perimysium) areas in 10 fields (200x magnification).

For statistical analysis, the Kolmogorov-Smirnov test was used to assess each parameter distribution. The clinical and demographic characteristics were expressed as mean \pm standard deviation (SD), for continuous variables, or as frequencies and percentages (\%), for categorical variables. The median (interquartile 25th to 75 th) was calculated for continuous variables that did not have a normal distribution. Comparisons between patient and control parameters were made using the Mann-Whitney test and Student $t$-test for continuous variables, while the Fisher's exact test or chi-square test were used to assess categorical variables. Spearman's correlation was used for analyzing the correlation (rho) between continuous variables and YKL- 40 values. Values between 0 and \pm 0.333 were considered weak; values between \pm 0.333 and \pm 0.666 were considered moderate; and those between \pm 0.666 and \pm 1.000 were considered strong." The relation between YKL-40 values and other variables (identified as the presence or absence of a certain characteristics) was performed using the Student $t$-test. To analyze the factors that together influence YKL-40, a multiple regression was performed considering all variables with $P$ value $<0.10$ as explanatory and the value of YKL-40 as dependent. A value of $P<0.05$ was adopted to indicate statistical significance. All analyses were performed using the statistical software SPSS version 22.0 (Chicago, IL, USA).

\section{Results}

Sixty-six patients with ASSD were initially included in the present study. Two patients were excluded, one due to overlap and the other due to neoplasia-associated myositis. No patients had acute or chronic infection, were pregnant, or had severe and decompensated comorbidities. Therefore, 64 patients with ASSD were evaluated and age-, gender-, and ethnicity-matched to 64 healthy controls (Fig. 1).

The mean age of the 64 patients with ASSD and of the 64 control individuals was $44.8 \pm 11.8$ years and $42.6 \pm$ 10.4 years, respectively $(P=0.278)$, with a predominance of females (82.8\% versus $82.8 \%, P>0.999)$, and Caucasians (73.4\% versus $73.4 \%, P>0.999)$ in both groups. The median ASSD disease duration was $1.5(0.0-4.0)$ years.

The initial and cumulative clinical manifestations, autoantibody panels, and comorbidities of patients with ASSD are shown in Table 1.

The current disease status of patients with ASSD at the time of inclusion in this study, lung parameters, and treatments are shown in Table 2.

YKL-40 serum levels were significantly higher in patients with ASSD when compared to the control group: 538.4 (363.4-853.1) $\mathrm{pg} / \mathrm{mL}$ versus 270.0 (201.8-451.9) $\mathrm{pg} / \mathrm{mL}$, respectively; $P<0.001$ (Table 2). Additionally, a significant increase in TNF- $\alpha$ levels was observed in patients with ASSD compared to the control group: 48.4 $(31.0-66.3) \mathrm{pg} / \mathrm{mL}$ versus $39.6(29.3-49.0) \mathrm{pg} / \mathrm{mL} ; P=$ 


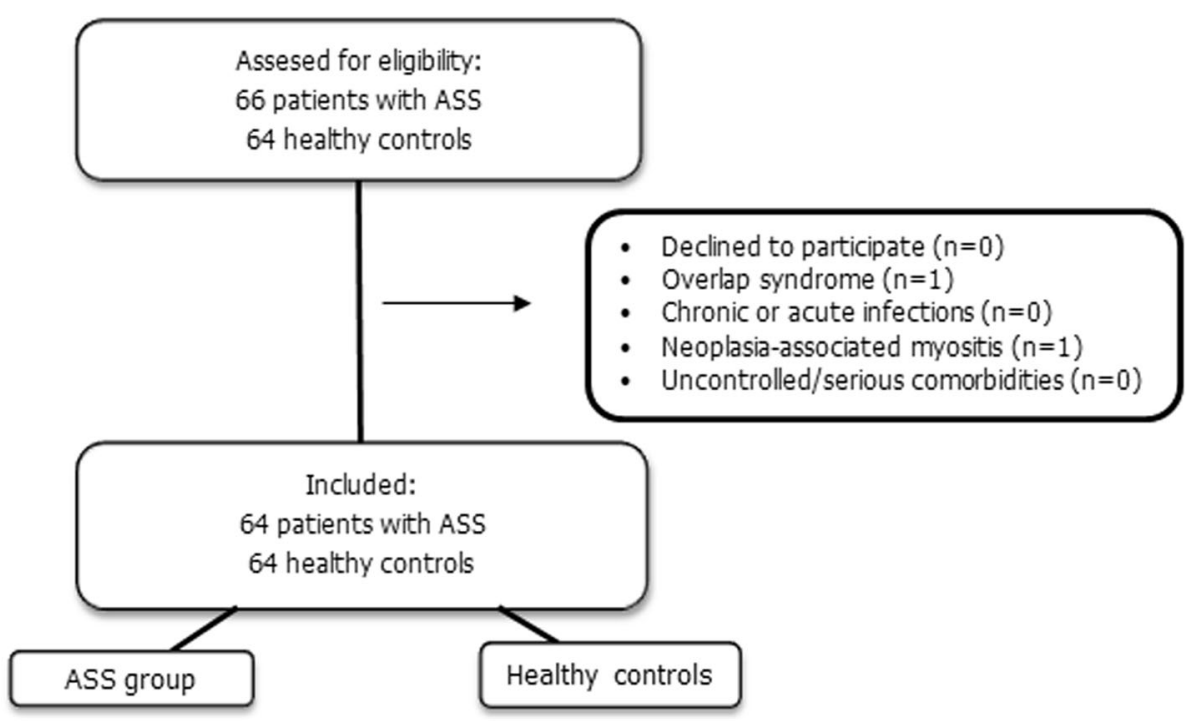

Fig. 1 Study flowchart. ASSD: antisynthetase syndrome

Table 1 Cumulative clinical manifestations, autoantibody panels, initial creatine phosphokinase serum levels, and comorbidities of the patients with antisynthetase syndrome

\begin{tabular}{ll}
\hline Antisynthetase syndrome & $\boldsymbol{n}=64$ \\
\hline Cumulative clinical manifestations & \\
Muscle involvement & $61(95.3)$ \\
Joint involvement & $59(92.2)$ \\
Lung involvement & $57(89.1)$ \\
$\quad$ Ground-glass & $46(71.9)$ \\
Incipient pneumopathy & $40(62.5)$ \\
$\quad$ Pulmonary fibrosis & $14(21.9)$ \\
Pulmonary nodules & $11(17.2)$ \\
"Mechanic's hands" & $57(89.1)$ \\
Raynaud's phenomenon & $50(78.1)$ \\
Fever & $46(71.9)$ \\
Autoantibody panels & \\
Antinuclear factor & $52(81.3)$ \\
Anti-Ro-52 & $28(43.8)$ \\
Anti-tRNA aminoacyl transferase & $64(100.0)$ \\
Anti-Jo-1 & $52(81.3)$ \\
Anti-PL-12, anti-PL-7 or anti-EJ & $12(18.7)$ \\
Anti-OJ & 0 \\
Initial creatine phosphokinase (U/L) & $3015(632-8463)$ \\
Comorbidities & \\
Systemic arterial hypertension & $22(34.4)$ \\
Diabetes mellitus & $12(18.8)$ \\
Hypothyroidism & $3(4.7)$ \\
Acute myocardial infarction & $3(4.7)$ \\
\hline & $1(1.6)$ \\
\hline
\end{tabular}

Data are expressed as mean \pm standard deviation (SD); median (interquartile 25 th - 75 th) or frequency (\%)
0.011. IFN- $\gamma$ serum levels were comparable in both groups.

Concerning demographic, clinical, laboratory, treatament, and comorbidity parameters, YKL-40 serum levels had correlation with patients' age (rho $=0.294 ; P=$ $0.040)$, TNF- $\alpha$ (rho $=0.382 ; P=0.007)$, and current use of prednisone $(P<0.047)$ - Tables 3 and 4 . However, in multivariate analysis, only TNF- $\alpha$ levels had significant factor to predict the YKL-40 values (Table 5).

Concerning the immunohistochemical analysis, YKL40 was expressed by inflammatory cells. Figure 2 shows a muscle biopsy specimen from a patient with ASSD.

\section{Discussion}

To the best of our knowledge, this study is the first to show the relevance of YKL-40 in patients with ASSD. High YKL-40 serum levels were observed in patients with ASSD and correlated positively with TNF- $\alpha$ serum levels. Besides, YKL-40 was expressed by inflammatory cells in muscle tissues.

Although ASSD is a rare disease, this study employed strict inclusion criteria to increase the specificity in the selection of the involved patients. In this context, a significant sample was included and paired by age, gender, and ethnicity with healthy individuals, thus allowing for greater accuracy in comparative outcomes. Finally, information on patients was based on parameterized and pre-standardized data to ensure reliable study data.

High YKL-40 expression is described in the pathogenesis of a number of diseases, and its utility as a biomarker has been the subject of several studies [8-18]. Biologically, YKL-40 can stimulate angiogenesis and a wide range of responses, such as inflammation, tissue 
Table 2 Demographic, current disease status, pulmonary involvement, treatment, and the cytokines serum levels of the patients with antisynthetase syndrome. Laboratory profiles of the control group

\begin{tabular}{|c|c|c|c|}
\hline & $\begin{array}{l}\text { ASSD } \\
(n=64)\end{array}$ & $\begin{array}{l}\text { Control } \\
(n=64)\end{array}$ & $\mathbf{P}$ \\
\hline \multicolumn{4}{|l|}{ IMACS set scores } \\
\hline MMT-8 (0-80) & $78(71-80)$ & - & \\
\hline Patient' VAS (0-10) & $4.0(2.0-6.0)$ & - & \\
\hline Physician' VAS (0-10) & $3.0(0.0-5.0)$ & - & \\
\hline MYOACT (0-60) & $4.0(0.5-2.5)$ & - & \\
\hline HAQ (0.00-3.00) & $0.67(0.13-1.38)$ & - & \\
\hline CPK (U/L) & $208(98-597)$ & $106(78-161)$ & $<0.001$ \\
\hline $\mathrm{LDH}(\mathrm{U} / \mathrm{L})$ & $352(243-590)$ & $346(312-345)$ & 0.937 \\
\hline AST (U/L) & $24(17-37)$ & $20(16-23)$ & 0.009 \\
\hline $\mathrm{ALT}(\mathrm{U} / \mathrm{L})$ & $24(16-57)$ & $18(13-25)$ & 0.030 \\
\hline \multicolumn{4}{|l|}{ Lung involvements } \\
\hline Ground-glass & $46(71.9)$ & - & \\
\hline Incipient pneumopathy & $40(62.5)$ & - & \\
\hline Pulmonary fibrosis & $14(21.9)$ & - & \\
\hline Pulmonary nodules & $11(17.2)$ & - & \\
\hline FVC (\% predict), $n=39$ & $62.5(48.0-73.5)$ & - & \\
\hline FEV1 (\% predicted), $n=39$ & $64(49-77)$ & - & \\
\hline FEV1/FVC ratio, $n=39$ & $0.90(0.93-1.08)$ & - & \\
\hline $\mathrm{DLCO}_{2}(\%$ predicted), $\mathrm{n}=39$ & $61.0(37.8-73.0)$ & - & \\
\hline \multicolumn{4}{|l|}{ Treatment } \\
\hline \multicolumn{4}{|l|}{ Prednisone } \\
\hline Current use & $46(71.9)$ & - & \\
\hline Dose (mg/day) & $10(0-40)$ & - & \\
\hline Immunosuppressive drugs & $47(73.4)$ & - & \\
\hline Azathioprine & $23(35.9)$ & - & \\
\hline Mycophenolate mofetil & $11(17.2)$ & - & \\
\hline Methotrexate & $14(21.9)$ & - & \\
\hline Antimalarial & $4(6.3)$ & - & \\
\hline Leflunomide & $2(3.1)$ & - & \\
\hline Cyclosporine & $3(4.7)$ & - & \\
\hline Cyclophosphamide & $1(1.7)$ & - & \\
\hline Rituximab & $16(25.0)$ & - & \\
\hline \multicolumn{4}{|l|}{ Cytokines } \\
\hline $\mathrm{YKL}-40(\mathrm{pg} / \mathrm{mL})$ & $538.4(363.4-853.1)$ & $270.0(201.8-451.9)$ & $<0.001$ \\
\hline IFNץ (pg/mL) & $0.02(0.00-1.89)$ & $0.02(0.00-0.17)$ & 0.876 \\
\hline TNFa (pg/mL) & $48.4(31.0-66.3)$ & $39.6(29.3-49.0)$ & 0.011 \\
\hline
\end{tabular}

Data are expressed as mean \pm standard deviation (SD); median (interquartile 25 th - 75 th) or frequency (\%)

$A L T$ alanine aminotransferase; $A S S D$ antisynthetase syndrome; $A S T$ aspartate aminotransferase; $C P K$ creatine phosphokinase; $D L C O_{2}$ diffusion of carbon dioxide; FEV1 forced expiratory volume in one second; FVC forced vital capacity; HAQ Health Assessment Questionnaire; IFN interferon; IMACS: International Myositis Assessment and Clinical Studies Group; LDH lactate dehydrogenase; MMT-8 Manual Muscle Testing; MYOACT Myositis Disease Activity Assessment Visual Analogue Scales; TNF tumor necrosis factor; VAS Visual Analog Scale; YKL chitinase-3-like-1 protein

remodeling, and allergic reactions. These responses are often mediated by other cytokines (e.g., IL-6, IL-18, and TNF- $\alpha$ ), which can regulate the YKL-40 secretion $[8,9]$.
YKL-40 is seldom described in studies regarding systemic autoimmune myopathies [19-21]. In this context, Hozumi et al. [19] showed high YKL-40 serum levels in 
Table 3 Correlation between YKL-40 serum levels and continuous variables (demographic, clinical, laboratory and lung parameters, and disease status) of the patients with antisynthetase syndrome

\begin{tabular}{|c|c|c|}
\hline & rho & $P$ \\
\hline \multicolumn{3}{|l|}{ Demographic data } \\
\hline Age & 0.294 & 0.040 \\
\hline \multicolumn{3}{|l|}{ Clinical parameters } \\
\hline Fever & 0.070 & 0.631 \\
\hline Raynaud phenomenon & 0.144 & 0.324 \\
\hline "Mechanic's hands" & -0.045 & 0.757 \\
\hline Muscle involvement & -0.219 & 0.131 \\
\hline Joint involvement & -0.190 & 0.192 \\
\hline \multicolumn{3}{|l|}{ Laboratory parameters } \\
\hline TNF-a level & 0.382 & 0.007 \\
\hline IFN- $\gamma$ level & 0.125 & 0.395 \\
\hline \multicolumn{3}{|l|}{ Lung involvement } \\
\hline FVC (\% predict) & 0.018 & 0.930 \\
\hline FEV1 (\% predicted) & 0.089 & 0.667 \\
\hline FEV1/FVC ratio & -0.066 & 0.758 \\
\hline $\mathrm{DLCO}_{2}(\%$ predicted $)$ & 0.533 & 0.091 \\
\hline \multicolumn{3}{|l|}{ Disease status } \\
\hline MMT-8 & 0.037 & 0.801 \\
\hline Patient' VAS & -0.173 & 0.239 \\
\hline Physician' VAS & -0.234 & 0.110 \\
\hline MYOACT & -0.077 & 0.614 \\
\hline $\mathrm{HAQ}$ & 0.166 & 0.266 \\
\hline Creatine phosphokinase & 0.131 & 0.371 \\
\hline Lactate dehydrogenase & 0.138 & 0.460 \\
\hline Aspartate aminotransferase & 0.033 & 0.854 \\
\hline Alanine aminotransferase & 0.034 & 0.866 \\
\hline \multicolumn{3}{|l|}{ Treatment } \\
\hline Prednisone: dose (mg/day) & 0.217 & 0.139 \\
\hline
\end{tabular}

$\mathrm{DLCO}_{2}$ diffusion of carbon dioxide; $F E V 1$ forced expiratory volume in one second; FVC forced vital capacity; HAQ Health Assessment Questionnaire; IFN interferon; MMT-8 Manual Muscle Testing; MYOACT Myositis Disease Activity Assessment Visual Analogue Scales; TNF tumor necrosis factor; VAS Visual Analog Scale

patients with dermatomyositis and polymyositis with associated interstitial lung disease, and YKL-40 serum levels were associated with a worse prognosis. Furthermore, the authors correlated YKL-40 levels negatively with DLCO and arterial oxygen pressure $\left(\mathrm{PaO}_{2}\right)$, finding a high expression of YKL-40 in alveolar macrophages and bronchial epithelial cells. Notably, the authors found that $42 \%$ of their patients had positive anti-aminoacyl-tRNA synthetase autoantibodies. Therefore, they might have included patients with ASSD and not necessarily pure dermatomyositis and polymyositis cases with associated interstitial lung disease. Additionally, patients with neoplasm associated myositis were included.

Gao et al. [20] also observed high YKL-40 serum levels in patients with dermatomyositis and polymyositis, which correlated positively with interstitial lung disease and with the disease activity and severity evaluated via MYOACT, C-reactive protein, ferritin, and erythrocyte sedimentation rates. However, the authors did not analyze anti-aminoacyl-tRNA synthetase autoantibodies in their patients.

Jiang et al. [21] observed a positive correlation between YKL-40 serum levels and patients with clinically amyopathic dermatomyositis and positive anti-MDA-5, especially in those with severe interstitial lung disease.

In our study, high YKL-40 serum levels were also observed in patients with ASSD. However, YKL-40 did not correlate with any clinical and laboratory parameters, disease status, or therapeutic schemes. There was also no correlation with any pulmonary parameters (e.g., patient's lung symptoms, chest CT images, and pulmonary function tests). Since this was a cross-sectional analysis, a prospective analysis of these parameters would be interesting.

To analyze disease status, Hozumi et al. [19] used variables such as ferritin, KL-6 (Krebs von den Lungen-6), SP-D (surfactant protein-D), $\mathrm{PaO}_{2}$, and DLCO, while Jiang et al. [21] used ferritin, CPK, T CD3+ cell count, C-reactive protein, FVC, and DLCO. In contrast, we used the IMACS set scores, which validated instruments for clinical evaluation in systemic autoimmune myopathies [23-27].

Unlike limited studies regarding YKL-40 in myositis, a limitation of our study was the fact that we did not specifically analyze the YKL-40 expression in lung biopsy specimens. Nonetheless, the YKL-40 expression analyzed in muscle specimens reinforces the hypothesis that YKL40 expression is systemic, not being limited to lung involvement.

YKL-40 can be expressed and secreted by various types of cells, including macrophages, neutrophils, and chondrocytes. Its expression is regulated by several cytokines, which mediate the proliferation, tissue remodeling, and production of other inflammatory mediators. In ASSD and systemic autoimmune inflammatory disease, the elevated YKL-40 serum levels might derive come from systemic inflammatory cells or local cells (e.g., blood, muscle, skin, lungs). This was the first study to demonstrate the increased expression of YKL-40 in the inflammatory cells of muscle tissue obtained from a patient with ASSD.

As previously mentioned, YKL-40 is regulated by various pro-inflammatory cytokines $[8,9]$; therefore, we assessed the TNF- $\alpha$ and IFN- $\gamma$ serum levels. 
Table 4 Relation between YKL-40 serum levels and others variables (demographic, clinical, laboratory and lung parameters, disease status, and comorbidities) of the patients with antisynthetase syndrome

\begin{tabular}{|c|c|c|c|c|c|}
\hline \multirow{3}{*}{ Demographic data } & \multicolumn{2}{|c|}{ Group 1} & \multicolumn{2}{|c|}{ Group 2} & \multirow[t]{2}{*}{$P$ value } \\
\hline & \multirow[t]{2}{*}{$\mathbf{n}$} & \multirow[t]{2}{*}{ Mean \pm SD } & \multirow[t]{2}{*}{$n$} & \multirow[t]{2}{*}{ Mean \pm SD } & \\
\hline & & & & & \\
\hline Gender (female) & 53 & $628.5 \pm 363.6$ & 11 & $691.3 \pm 461.0$ & 0.658 \\
\hline Ethnicity (Caucasian) & 47 & $572.5 \pm 316.7$ & 17 & $793.2 \pm 468.2$ & 0.111 \\
\hline \multicolumn{6}{|l|}{ Clinical parameters } \\
\hline Fever & 18 & $579.4 \pm 343.8$ & 46 & $664.3 \pm 394.0$ & 0.484 \\
\hline Raynaud phenomenon & 14 & $536.6 \pm 361.8$ & 50 & $677.4 \pm 382.7$ & 0.255 \\
\hline "Mechanic's hands" & 7 & $658.6 \pm 334.6$ & 57 & $637 \pm 389.2$ & 0.891 \\
\hline Muscle involvement & 3 & $980.2 \pm 178.7$ & 61 & $625.6 \pm 379.2$ & 0.198 \\
\hline Joint involvement & 5 & $973.5 \pm 602.1$ & 59 & $610.4 \pm 347.5$ & 0.066 \\
\hline \multicolumn{6}{|l|}{ Laboratory parameters } \\
\hline Antinuclear factor & 12 & $685.7 \pm 303.5$ & 52 & $628.4 \pm 398.4$ & 0.674 \\
\hline Anti-Ro-52 & 35 & $663.9 \pm 406.5$ & 28 & $638.5 \pm 348.0$ & 0.818 \\
\hline Anti-Jo-1 & 11 & $728.4 \pm 455.9$ & 53 & $617.4 \pm 359.7$ & 0.414 \\
\hline Anti-PL-7 & 60 & $619.1 \pm 377.6$ & 4 & $876.1 \pm 351.5$ & 0.197 \\
\hline Anti-PL-12 & 60 & $627.2 \pm 360.9$ & 4 & $784.8 \pm 595.5$ & 0.431 \\
\hline Anti-EJ & 61 & $653.7 \pm 380.8$ & 3 & $320.4 \pm 52.2$ & 0.227 \\
\hline \multicolumn{6}{|l|}{ Lung involvement } \\
\hline Ground-glass & 18 & $658.2 \pm 348.1$ & 46 & $634.2 \pm 392.6$ & 0.851 \\
\hline Incipient pneumopathy & 24 & $695.9 \pm 387.1$ & 40 & $607.6 \pm 376.4$ & 0.437 \\
\hline Pulmonary fibrosis & 50 & $586.2 \pm 335.7$ & 14 & $826.2 \pm 471.8$ & 0.063 \\
\hline \multicolumn{6}{|l|}{ Treatment } \\
\hline Prednisone (current use) & 17 & $483.3 \pm 222.6$ & 46 & $684.2 \pm 406.3$ & 0.047 \\
\hline \multicolumn{6}{|l|}{ Immunosuppressives/biologicals } \\
\hline Azathioprine & 43 & $618.9 \pm 354.7$ & 21 & $676.5 \pm 425.2$ & 0.613 \\
\hline Mycophenolate mofetil & 54 & $648.4 \pm 383.8$ & 10 & $603.1 \pm 375.2$ & 0.750 \\
\hline Methotrexate & 52 & $606.3 \pm 338.1$ & 12 & $790.3 \pm 521.9$ & 0.337 \\
\hline Antimalarial & 61 & $645.3 \pm 385.8$ & 3 & $516.7 \pm 91.7$ & 0.643 \\
\hline Leflunomide & 62 & $642.1 \pm 382.5$ & 2 & $544.0 \pm 0$ & 0.801 \\
\hline Cyclosporine & 62 & $650.8 \pm 381.1$ & 2 & $388.7 \pm 272.8$ & 0.343 \\
\hline Cyclophosphamide & 63 & $644.0 \pm 381.8$ & 1 & $451.9 \pm 0$ & 0.621 \\
\hline Rituximab & 48 & $690.0 \pm 364.8$ & 16 & $537.0 \pm 397.9$ & 0.188 \\
\hline \multicolumn{6}{|l|}{ Comorbidities } \\
\hline Systemic arterial hypertension & 42 & $590.4 \pm 379.9$ & 22 & $742.5 \pm 366.9$ & 0.190 \\
\hline Diabetes mellitus & 52 & $645.1 \pm 395.0$ & 12 & $610.0 \pm 283.2$ & 0.823 \\
\hline Hypothyroidism & 61 & $628.0 \pm 381.0$ & 3 & $922.5 \pm 205.8$ & 0.286 \\
\hline Acute myocardial infarction & 61 & $641.6 \pm 382.6$ & 3 & $567.2 \pm 0$ & 0.848 \\
\hline Stroke & 63 & $645.2 \pm 381.0$ & 1 & $391.6 \pm 0$ & 0.513 \\
\hline
\end{tabular}

$S D$ standard deviation

High TNF- $\alpha$ serum levels were observed in patients with ASSD, similar to what occurs in other systemic autoimmune myopathies [31, 32]. TNF- $\alpha$ can induce YKL-40 production [8]. These data corroborated our study, in which a positive correlation was found between YKL-40 and TNF- $\alpha$ serum levels.

Although IFN- $\gamma$ is involved in the ASSD pathophysiology, we did not find high cytokine serum levels in the 
Table 5 Multivariate analysis

\begin{tabular}{llllll}
\hline & Coefficient & Standard error & $\begin{array}{l}\text { Lower } \\
\text { Cl (95\%) }\end{array}$ & $\begin{array}{l}\text { Upper } \\
\text { Cl (95\%) }\end{array}$ & $\begin{array}{c}\text { P value } \\
\text { (Constant) }\end{array}$ \\
TNF a level & 374.3 & 105.6 & 161.6 & 587.0 & 0.001 \\
\hline
\end{tabular}

$\mathrm{R}^{2}=0.163$

$\mathrm{Cl}$ confidence interval

present study. IFN- $\gamma$ has a transient effect, being quickly cleared in the bloodstream [31, 33]. Therefore, it is difficult to detect. In the pathophysiology of systemic autoimmune myopathies, the participation of Th1 and Th2 cells is described as follows: IFN- $\gamma$ is produced by initially present Th1 cells and, then, Th1 cells regulate Th2 cells using other inflammatory cytokines, including YKL-40 $[34,35]$.
The present study had some limitations. First, spirometry was not performed in all patients because of various internal circumstances, such as patients with difficulty in performing spirometry (dyspnea) and lack of available spirometry equipment at patient selection, even with these tests being carried out only in a later phase of the ASSD diagnosis and treatment (> six months). Second, the degree of dyspnea, six-minute walking distance, and
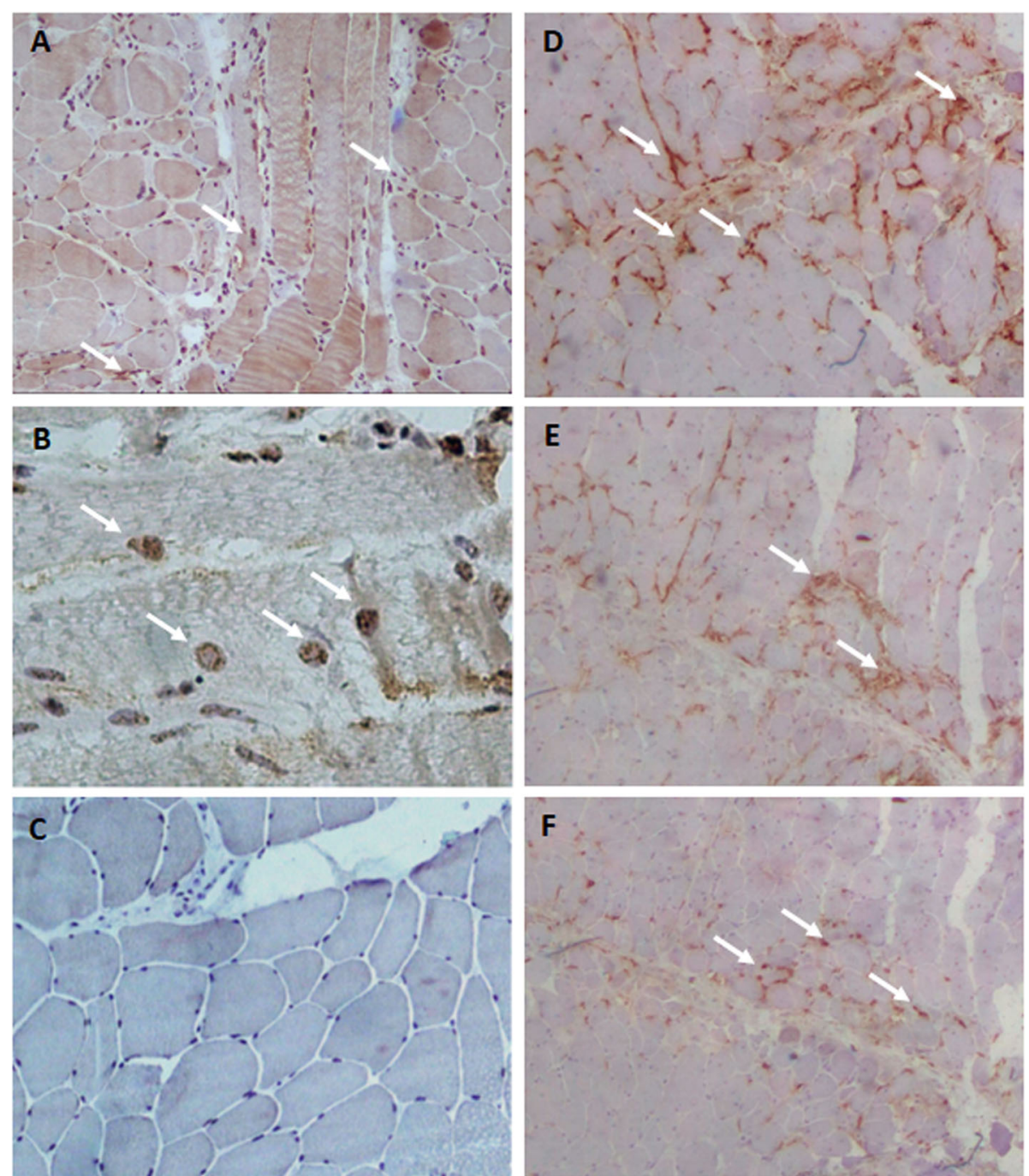

Fig. 2 Expression of YKL-40 in a muscle specimen from a patient with antisynthetase syndrome. Positive immunohistochemistry reaction of (A) YKL-40, (B) YKL-40*; (D) CD68, (E) CD4, and (F) CD8. Magnification is 200x or 400x*. As a negative control of YKL-40 (C), a specimen from a patient with antisynthetase syndrome, but without infiltrate inflammation 
oxygen saturation were not analyzed. Third, the analysis of pneumopathy in CT was only descriptive, since there is no criterion in sytemic autoimmune myopathies that quantifies the degree of lung involvement.

\section{Conclusions}

This study showed high YKL-40 serum levels in patients with ASSD, and these correlated positively with TNF- $\alpha$ serum levels. Although other studies have shown the expression of YKL-40 in lungs of patients with various systemic autoimmune myopathies, we have shown high YKL-40 levels in inflammatory muscle tissue cells.

\section{Abbreviations}

ALT: Alanine aminotransferase; ANA: Antinuclear antibodies; ASSD: Antisynthetase syndrome; AST: Aspartate aminotransferase; CO: Carbon monoxide; CPK: Creatine phosphokinase; CT: Computed tomography; FEV1: Forced expiratory volume in one second; FVC: Forced vital capacity; HAQ: Health Assessment Quality; HE: Hematoxylin-eosin; IMACS: International Myositis Assessment and Clinical Studies Group; LDH: Lactate dehydrogenase; MMT: Manual Muscle Testing; MYOACT: Myositis Disease Activity Assessment Visual Analogue Scales; PBS: Phosphate buffered saline; Rho: Correlation; TNF: Tumor necrosis factor; VAS: Visual analogue scale; YKL40: Protein chitinase-3-like-1

\section{Acknowledgments}

Not applicable.

\section{Authors' contributions}

All authors contributed equally to write and review the manuscript. The author(s) read and approved the final manuscript.

\section{Funding}

Fundação de Amparo à Pesquisa do Estado de São Paulo (FAPESP) \#2014/ 09079-1, Conselho Nacional de Desenvolvimento Científico e Tecnológico (CNPq) \#303379/2018-9 and Faculdade de Medicina da USP - SP to SKS.

\section{Availability of data and materials} Not applicable.

\section{Declarations}

\section{Ethics approval and consent to participate}

The study was approved by the local ethics committee (CAAE: 89386618.0.0000.0068) and all participants signed the informed consent form.

\section{Consent for publication}

Not applicable.

\section{Competing interests}

All authors declare that they have no conflicts of interest.

Received: 11 December 2020 Accepted: 21 June 2021

Published online: 05 July 2021

\section{References}

1. Connors GR, Christopher-Stine L, Oddis CV, Danoff SK. Interstitial lung disease associated with the idiopathic inflammatory myopathies: what progress has been made in the past 35 years? Chest. 2010;138(6):1464-74. https://doi.org/10.1378/chest.10-0180.

2. Cavagna L, Trallero-Araguás E, Meloni F, Cavazzana I, Rojas-Serrano J, Feist E, et al. Influence of antisynthetase antibodies specificities on antisynthetase syndrome clinical spectrum time course. J Clin Med. 2019;8(11):2013. https:// doi.org/10.3390/jcm8112013.

3. Shinjo SK, Levy-Neto M. Anti-Jo-1 antisynthetase syndrome. Rev Bras Reumatol. 2010;50(5):492-500. https://doi.org/10.1590/S0482-5004201 0000500003 .
4. González-Gay MA, Montecucco C, Selva-O'Callaghan A, Trallero-Aragua E, Molberg $\mathrm{O}$, Andersson $\mathrm{H}$, et al. Timing of onset affects arthritis presentation pattern in antisyntethase syndrome. Clin Exp Rheumatol. 2018;36(1):44-9.

5. Hakala BE, White $C$, Recklies AD. Human cartilage gp-39, a major secretory product of articular chondrocytes and synovial cells, is a mammalian member of a chitinase protein family. J Biol Chem. 1993;268(34):25803-10. https://doi.org/10.1016/S0021-9258(19)74461-5.

6. De Ceuninck F, Gaufillier S, Bonnaud A, Sabatini M, Lesur C, Pastoureau P. YKL-40 (cartilage gp-39) induces proliferative events in cultured chondrocytes and synoviocytes and increases glycosaminoglycan synthesis in chondrocytes. Biochem Biophys Res Commun. 2001;285(4):926-31. https://doi.org/10.1006/bbrc.2001.5253.

7. Lee CG, Da Silva CA, Dela Cruz CS, Ahangari F, Ma B, Kang MJ, et al. Role of chitin and chitinase/chitinase-like proteins in inflammation, tissue remodeling, and injury. Annu Rev Physiol. 2011;73(1):479-501. https://doi. org/10.1146/annurev-physiol-012110-142250.

8. Prakash M, Bodas M, Prakash D, Nawani N, Khetmalas M, Mandal A, et al. Diverse pathological implications of YKL-40: answers may lie in 'outside-in' signaling. Cell Signal. 2013;25(7):1567-73. https://doi.org/10.1016/j.cellsig.2 013.03.016.

9. Kazakova MH, Batalov AZ, Mateva NG, Sarafian VS. YKL-40 and cytokines-a new diagnostic constellation in rheumatoid arthritis? Folia Med. 2017;59(1): 37-42. https://doi.org/10.1515/folmed-2017-0013.

10. Huang K, Wu LD. YKL-40: a potential biomarker for osteoarthritis. J Int Med Res. 2009;37(1):18-24. https://doi.org/10.1177/147323000903700102.

11. Johansen JS, Stoltenberg M, Hansen M, Florescu A, Horslev-Petersen K, Lorenzen I, et al. Serum YKL-40 concentrations in patients with rheumatoid arthritis: relation to disease activity. Rheumatology (Oxford). 1999;38(7):61826. https://doi.org/10.1093/rheumatology/38.7.618.

12. Jafari-Nakhjavani MR, Ghorbanihaghjo A, Bagherzadeh-Nobari B, MalekMahdavi A, Rashtchizadeh N. Serum YKL-40 levels and disease characteristics in patients with rheumatoid arthritis. Caspian J Int Med. 2019. 10:92-7.

13. Väänänen $T$, Vuolteenaho $K$, Kautiainen $H$, Nieminen $R$, Mottonen $T$, Hannonen P, et al. NEO-RACo Study Group. Glycoprotein YKL-40: A potential biomarker of disease activity in rheumatoid arthritis during intensive treatment with cSDMARDs and infliximab. Evidence from the randomised controlled NEO-RACo trial. PLoS One. 2017;12:e0183294.

14. Peltomaa R, Paimela L, Harvey S, Helve T, Leirisalo-Repo M. Increased level of YKL-40 in sera from patients with early rheumatoid arthritis: a new marker for disease activity. Rheumatol Int. 2001;20(5):192-6. https://doi.org/1 $0.1007 / \mathrm{s} 002960100115$.

15. Johansen JS, Baslund B, Garbarsch C, Hansen M, Stoltenberg M, Lorenzen I, et al. YKL-40 in giant cells and macrophages from patients with giant cell arteritis. Arthritis Rheum. 1999;42(12):2624-30. https://doi.org/10.1002/15290131(199912)42:12<2624::AID-ANR17>3.0.CO;2-K

16. Montagna GL, D'Angelo S, Valentini G. Cross-sectional evaluation of YKL-40 serum concentrations in patients with systemic sclerosis. Relationship with clinical and serological aspects of disease. Rheumatolology. 2003;30:2147-51.

17. Nordenbaek C, Johansen JS, Halberg P, Wiik A, Garbarsch C, Ullman S, et al. High serum levels of YKL-40 in patients with systemic sclerosis are associated with pulmonary involvement. Scand J Rheumatol. 2005;34(4): 293-7. https://doi.org/10.1080/03009740510018598.

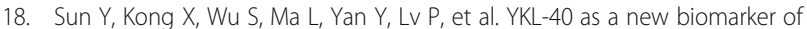
disease activity in Takayasu arteritis. Int J Cardiol. 2019;293:231-7. https://doi. org/10.1016/j.ijcard.2019.06.058.

19. Hozumi H, Fujisawa T, Enomoto N, Nakashima R, Enomoto Y, Suzuki Y, et al. Clinical utility of YKL-40 in polymyositis/dermatomyositis-associated interstitial lung disease. J Rheumatol. 2017;44(9):1394-401. https://doi.org/1 0.3899 /jrheum.170373.

20. Gao MZ, Wei YY, Xu QW, Ji R, Han Z-J, Jian T-W, et al. Elevated serum YKL40 correlates with clinical characteristics in patients with polymyositis or dermatomyositis. Ann Clin Biochem. 2019;56(1):95-9. https://doi.org/10.11 77/0004563218786979.

21. Jiang L, Wang Y, Peng Q, Shu X, Wang G, Wu X, et al. Serum YKL-40 level is associated with severity of interstitial lung disease and poor prognosis in dermatomyositis with anti-MDA5 antibody. Clin Rheumatol. 2019;38(6): 1655-63. https://doi.org/10.1007/s10067-019-04457-w.

22. Cruellas MG, Viana V dos S, Levy-Neto M, FHC DS, Shinjo SK. Myositisspecific and myositis-associated autoantibody profiles and their clinical 
associations in a large series of patients with polymyositis and dermatomyositis. Clinics. 2013;68:909-14.

23. Rider LG, Giannini EH, Harris-Love M, Joe G, Isenberg D, Pilkington C, et al. International myositis assessment and clinical studies group. Defining clinical improvement in adult and juvenile myositis. J Rheumatol. 2003;30(3): 603-17.

24. Rider LG, Feldman BM, Perez MD, Rennebohm RM, Lindsley CB, Zemel LS, et al. Development of validated disease activity and damage indices for the juvenile idiopathic inflammatory myopathies: I. physician, parent, and patient global assessments. Juvenile dermatomyositis disease activity collaborative study group. Arthritis Rheum. 1997;40(11):1976-83. https://doi. org/10.1002/art.1780401109.

25. Harris-Love MO, Shrader JA, Koziol D, Pahlajani N, Jain M, Smith M, et al. Distribution and severity of weakness among patients with polymyositis, dermatomyositis, and juvenile dermatomyositis. Rheumatology (Oxford). 2009;48(2):134-9. https://doi.org/10.1093/rheumatology/ken441.

26. Miller FW, Rider GL, Chung YL, et al. International Myositis Outcome Assessment Collaborative Study Group. Proposed preliminary core set measures for disease outcome assessment in adult and juvenile idiopathic inflammatory myopathies. Rheumatology (Oxford). 2001;40:1262-73.

27. Bruce B, Fries JF. The Stanford health assessment questionnaire: dimensions and practical applications. Health Qual Life Outcomes. 2003;1 (1):20. https:// doi.org/10.1186/1477-7525-1-20.

28. Waseda Y, Johkoh T, Egashira R, Sumikawa H, Saeki K, Watanabe S, et al. Antisynthetase syndrome: pulmonary computed tomography findings of adult patients with antibodies to aminoacyl-tRNA synthetases. Eur J Radiol. 2016;85(8):1421-6. https://doi.org/10.1016/j.ejrad.2016.05.012.

29. Debray MP, Borie R, Revel MP, Naccache J-M, Khalil A, Toper C, et al. Interstitial lung disease in anti-synthetase syndrome: initial and follow-up CT findings. Eur J Radiol. 2015;84(3):516-23. https://doi.org/10.1016/j.jrad.2 014.11.026.

30. Sada KE, Yamasaki Y, Maruyama M, Sugiyama H, Yamamura M, Maeshima $Y$, et al. Altered levels of adipocytokines in association with insulin resistance in patients with systemic lupus erythematosus. J Rheumatol. 2006;33(8): 1545-52.

31. Salomonsson S, Lundberg IE. Cytokines in idiopathic inflammatory myopathies. Autoimmunity. 2006;39(3):177-90. https://doi.org/10.1080/0891 6930600622256.

32. Lundberg I, Brengman JM, Engel AG. Analysis of cytokine expression in muscle in inflammatory myopathies, Duchenne dystrophy, and non-weak controls. J Neuroimmunol. 1995;63(1):9-16. https://doi.org/10.1016/0165-572 8(95)00122-0.

33. Gallay L, Mouchiroud G, Chazaud B. Interferon-signature in idiopathic inflammatory myopathies. Curr Opin Rheumatol. 2019;31(6):634-42. https:// doi.org/10.1097/BOR.0000000000000653.

34. Hou C, Baba-Amer Y, Bencze M, Relaix F, Authier FJ. The effect of interferongamma on skeletal muscle cell biology. Med Sci. 2018;34:35-8.

35. Isoda K, Kotani T, Takeuchi T, Kiboshi T, Hata K, Ishida T, et al. Comparison of long-term prognosis and relapse of dermatomyositis complicated with interstitial pneumonia according to autoantibodies: anti-aminoacyl tRNA synthetase antibodies versus antimelanoma differentiation-associated gene 5 antibody. Rheumatol Int. 2017;37(8):1335-40. https://doi.org/10.1007/s002 96-017-3729-y

\section{Publisher's Note}

Springer Nature remains neutral with regard to jurisdictional claims in published maps and institutional affiliations.

Ready to submit your research? Choose BMC and benefit from:
- fast, convenient online submission
- thorough peer review by experienced researchers in your field
- rapid publication on acceptance
- support for research data, including large and complex data types
- gold Open Access which fosters wider collaboration and increased citations
- maximum visibility for your research: over 100M website views per year
At BMC, research is always in progress.
Learn more biomedcentral.com/submissions

